\title{
Alternative Für Deutschland Strategy in 2017 Germany Legislative Election: Analysis of Posters as Visual Campaign Media Strategi Kampanye Partai Alternative Für
Deutschland Pada Pemilihan Legislatif
Jerman Tahun 2017: Analisis Poster
Sebagai Media Kampanye Visual
}

\author{
Nafila Maulina Priyanto \\ Universitas Pembangunan Nasional "Veteran” Jawa Timur
}

\begin{abstract}
ABSTRAK
Paham Populisme-Ekstrem Sayap Kanan mengalami kenaikan di Eropa utamanya pascakrisis pengungsi 2014-2015. Krisis ini menjadi momentum bagi partai populis ekstrem sayap kanan untuk memobilisasi suara masyarakat. Di Jerman, partai Alternative für Deutschland (AfD) mendapat dukungan yang masif ketika partai memutuskan untuk berfokus pada ideologi dan kritiknya mengenai krisis pengungsi Eropa pada pemilihan legislatif tahun 2017. Salah satu cara strategi yang digunakan oleh partai adalah dengan kampanye melalui poster. Oleh karena itu, untuk menjawab pertanyaan bagaimana karakter populis ekstrem sayap kanan direpresentasikan dalam poster kampanye partai AfD, penelitian ini menggunakan konsep Populisme Sayap Kanan dan teori Strategic Political Communication yang dianalisis dengan menggunakan metode CDA untuk dapat menganalisis poster secara spesifik. Penelitian ini menyimpulkan bahwa partai AfD lebih menunjukkan karakter rasis pada poster-poster kampanyenya yang ditunjukkan oleh atribut-atribut budaya yang digunakan.
\end{abstract}

Kata-kata kunci: Populisme-ekstrem sayap kanan; Alternative Für Deutschland; Krisis Pengungsi Eropa

Right-wing populism-extreme views have increased in Europe, especially after the 2014-2015 refugee crisis. This crisis has become a momentum for extreme right-wing populist parties to mobilize people's voices. In Germany, the Alternative für Deutschland (AfD) party received massive support when it decided to focus on its ideology and criticism of the European refugee crisis in the 2017 legislative elections. One of the strategies used by the party was through poster campaigns. Therefore, to answer how the extreme right-wing populist character is represented in the AfD party's campaign poster, this study uses the concept of Right-wing Populism and the theory of Strategic Political Communication, which is analyzed using the CDA method be able to analyze the poster specifically. This study concludes that the AfD party shows more of a racist character on its campaign posters which is indicated by the cultural attributes used.

Keywords: Alternative für Deutschland, Right-wing extremism, Refugee Crisis 
Populisme berhaluan ekstrem sayap kanan menjadi sebuah topik yang hangat dalam satu dekade terakhir pada konstelasi sosiopolitik dunia (Haidt 2016). Kemenangan Donald Trump pada pemilihan presiden tahun 2016 di Amerika Serikat dan keluarnya Inggris dari Uni Eropa pada Bulan Maret 2017 adalah dua sign post yang besar atas kebangkitan haluan politik ini. Selain keluarnya Inggris dari Uni Eropa, kebangkitan populisme ekstrem sayap kanan dibuktikan dengan munculnya gerakan sosial dan partai politik yang muncul hampir di seluruh negara di Benua Eropa (Mudde 2007).

Di Austria misalnya, partai populisme ekstrem sayap kanan, Freedom Party (dalam Bahasa Jerman Freiheitliche Partei Österreichs; FPÖ), yang terbentuk pada tahun 1956 mendapatkan hasil suara tertingginya di tahun 2017 dengan jumlah suara 27\% dan berhasil membentuk koalisi di pemerintahan (Schain 2018). Di Belanda, Party for Freedom (dalam Bahasa Belanda, Partij voor de Vrijheid; PVV), yang dibentuk pada tahun 2006 berhasil memperoleh suara tertingginya pada tahun 2010 dengan jumlah suara $15 \%$ dan juga berhasil membentuk koalisi partai di parlemen (Schain 2018). Tren yang sama juga ditemukan di negara lain di Eropa seperti Belgia, Denmark, Perancis, Jerman, Italia, Belanda, Norwegia, dan Swiss yang juga mengalami kenaikan popularitas partai ekstrem sayap kanan (Schain 2018). Tidak hanya itu, kehadiran gerakan PEGIDA (dalam Bahasa Jerman: Patriotische Europäer gegen die Islamisierung des Abendlandes. Dalam Bahasa Inggris: Patriotic Europeans Against the Islamisation of the Occident) di Jerman yang berhasil berjejaring di negaranegara Eropa lainnya juga semakin memperkuat jaringan gerakan ekstrem sayap kanan ini.

Pada tahun 2014, Eropa mengalami surplus pengungsi yang melimpah dan mencapai puncaknya pada tahun 2015. Peristiwa ini kemudian disebut sebagai Europe Refugee Crisis atau krisis pengungsi Eropa. Pada 7 Desember 2015, tercatat setidaknya sebanyak 2,614,306 pengungsi yang datang dari negara berkonflik di kawasan Timur Tengah - Suria, Afghanistan, dan Irak masuk ke wilayah Eropa (Overseas Development Institute 2016). Pew Research Centre mencatat jumlah pengungsi yang datang ke Benua Eropa pada tahun 2015 setidaknya sepuluh kali lipat lebih banyak daripada jumlah pengungsi yang datang ke Eropa pada tahun 1985, membuat 2015 menjadi tahun dengan jumlah pengungsi terbanyak sejak tahun 1985 di Eropa (Pew Research Centre 2018). 
Jerman merupakan negara dengan jumlah penerimaan pengungsi terbesar di Eropa yang menerima setidaknya sebanyak 1,301,068 pada tahun 2015 dan merupakan jumlah pengungsi terbanyak yang masuk ke Jerman sejak tahun 1991. Ternyata, penerimaan pengungsi ini tidak disertai dengan sambutan yang baik dari masyarakat di negara penerima (Koptyung 2020). Banyaknya jumlah pengungsi yang masuk menyebabkan kecemasan pada level individu dan komunitas di negara penerima. Latar belakang para pengungsi yang masuk ke wilayah Eropa pada tahun 2015, yang sebagian besar berasal dari negara timur tengah dan mayoritas beragama Islam ${ }^{1}$, menciptakan sebuah benturan identitas di kalangan masyarakat. Dikotomi "barat" dan "timur" ini memunculkan sebuah benturan yang oleh Samuel P. Huntington disebut sebagai Clash of Civilization ${ }^{2}$. Di Jerman, Dalia Research menemukan bahwa hampir 50\% masyarakat Jerman menilai bahwa banyaknya pengungsi akan menimbulkan dampak negatif terhadap budaya Jerman (Wilhelm 2018).

Tabel 1.

Jumlah kasus pengungsi di Eropa

\begin{tabular}{|l|c|}
\hline \multicolumn{1}{|c|}{ Negara } & Jumlah kasus pengungsi \\
\hline Jerman & $\mathbf{1 , 3 0 1 , 0 6 8}$ \\
\hline Italia & $\mathbf{1 9 7 , 7 3 9}$ \\
\hline Swedia & 179,017 \\
\hline Perancis & $\mathbf{1 4 9 , 3 3 2}$ \\
\hline
\end{tabular}

1 Pada tahun 2015, setidaknya lebih dari 350.000 pengungsi berasal dari Syria, sekitar 175.000 pengungsi berasal dari Afghanistan, dan lebih dari 100.000 pengungsi berasal dari Iraq, disusul oleh Kosovo, Albania, dan Pakistan. Oleh karena itu, karena hampir seluruh pengungsi berasal dari wilayah timur tengah yang mayoritas adalah Muslim, maka tabrakan identitas atau tabrakan peradaban terjadi adalah tabrakan antara peradaban barat dan peradaban Islam. Lihat BBC News. (2016). Diakses dari https://www.bbc.com/ news/world-europe-34131911. Pada 31 Oktober 2020

2 Clash of Civilization adalah istilah yang dipopulerkan oleh Samuel P. Huntington yang berpendapat bahwa setelah perang dunia ke-2, konflik yang akan banyak terjadi adalah konflik antar peradaban, bukan konflik ideologi dan ekonomi karena identitas/budaya/ peradaban adalah kebutuhan dasar setiap manusia. Huntington membagi peradaban di dunia menjadi delapan: peradaban Barat, Peradaban Konghucu atau Konfusianisme, peradaban Jepang, peradaban Islam yang dibangun berdasarkan ajaran-ajaran Islam, peradaban Hindu, peradaban Slavia-Ortodoks, peradaban Amerika Latin, dan peradaban Afrika. Dalam kasus pengungsi, peradaban yang berbenturan adalah peradaban Barat atau peradaban Eropa dan peradaban timur atau peradaban Islam. Lihat Samuel, H. (1993). The clash of civilizations. New York: Simon \& Schuster. Hlm. 45-48. 
Alternative Für Deutschland Strategy in 2017 Germany Legislative Election: Analysis of Posters as Visual Campaign Media

\begin{tabular}{|l|c|}
\hline Hongaria & 114,365 \\
\hline Austria & 136,208 \\
\hline Total Uni Eropa & $2,614,306$ \\
\hline
\end{tabular}

Sumber: International Organization for Migration. Disunting oleh penulis.

Robert Schuman Centre for Advanced Studies (RCAS) menyatakan bahwa pada kurun waktu 2014 sampai 2016 saat krisis pengungsi melanda Eropa, terdapat kenaikan tren atas pentingnya isu pengungsi di Benua Eropa (Dennison \& Talõ 2017). Isu pengungsi di Jerman mengalami kenaikan tren setidaknya sekitar 5\% pada tahun 2014-2016 dibandingkan dengan tahun 2012-2014. Hasil survei Eurobarometer tahun 2019 juga menyatakan bahwa kasus pengungsi menjadi isu teratas sejak tahun 2017-2019(Ortjens 2020). Sebagai negara di Eropa dengan penerimaan jumlah pengungsi terbanyak, Jerman juga mengalami krisis pengungsi yang tidak hanya menjadi permasalahan sosial, tapi juga politik. Krisis ini diusung oleh partai Alternative für Deutschland (AfD) yang menggunakan isu pengungsi sebagai momentum untuk alat kampanye mereka. Pada pemilihan legislatif tahun 2017, partai AfD mendapat kemenangan yang signifikan dengan hasil suara sebanyak $11,5 \%$ pada putaran pertama dan $12,6 \%$ di putaran kedua (The Federal Returning Officer 2017). Hasil ini signifikan apabila dibandingkan dengan pemilihan parlemen sebelumnya pada tahun 2013 dengan hasil suara hanya 4,7\%.

Maximilian Rau dalam The Power of Insecurity Narratives in Populist Social Media: The Far-Right Attempt of Reclaiming Conversation menjelaskan bahwa partai AfD mengandalkan peristiwa-peristiwa kecil untuk membingkai "musuh" di dalam masyarakat yang menjunjung tinggi Germaneness (Rau 2017). Sedangkan Annika Reitz dalam Political Campaign Strategies of the Party Alternative for Germany mengatakan bahwa partai AfD menyorot satu konflik utama yakni masyarakat Jerman versus para pengungsi (Reitz 2019). Selain itu, Adina-Elena Cincu dalam Farright Populist Challenge in Europe: Alternative for Germany and National Front menjelaskan bahwa AfD dan FN memposisikan mereka sebagai us vs them dalam kebijakan mengenai pengungsi (Cincu 2017).

Berdasarkan latar belakang yang telah dijelaskan, maka rumusan masalah dalam tulisan ini adalah "Bagaimana Karakter PopulisEkstrem Sayap Kanan Direpresentasikan dalam Poster-Poster 
Kampanye Legislatif Partai Alternative Fur Deutschland sebagai Strategi Komunikasi Politik?”. Untuk menjawab pertanyaan ini, penulis akan menggunakan konsep populisme sayap kanan dan teori strategic political communication yang akan dianalisis menggunakan metode critical discourse analysis.

\section{Tinjauan Pustaka}

Untuk menganalisis tentang populisme sayap kanan di Jerman yang direpresentasikan oleh Partai AfD, penulis akan menggunakan beberapa literatur sebagai tinjauan atas penelitianpenelitian terdahulu dan sebagai pijakan atas penelitian yang akan penulis lakukan. Artikel pertama, yakni dari Berbuir, et al., (2014) dalam The AfD and its Sympathisers: Finally a Right-Wing Populist Movement in Germany? yang menganalisis bagaimana munculnya AfD dalam perpolitikan Jerman pada tahun 2013. Berbuir mencoba menganalisis tentang karakter AfD dari posisi politik yang dipilih dan para pendukungnya, bagaimana AfD menggunakan media sebagai alat kampanye, dan bagaimana AfD mengkampanyekan dirinya dalam konstelasi politik Jerman. Riset ini dilakukan dengan metode kualitatif yang didasarkan pada kajian sejarah Jerman dan data sekunder. Berbuir memilih populisme, nasionalisme, globalisme, dan liberal-konservatisme sebagai landasan teori. Hasil dari riset ini menyatakan bahwa AfD tidak memberikan dampak yang signifikan terhadap perpolitikan Jerman, apalagi terhadap tren populisme sayap kanan. Berbuir melihat bahwa AfD seyogyanya bukanlah partai berhaluan sayap kanan, ia hanya populis, tetapi tidak memenuhi syarat-syarat untuk dikatakan sebagai partai sayap kanan.

Kedua, Lees (2018), dalam The 'Alternative for Germany': The rise of right-wing populism at the heart of Europe secara implisit menyatakan bahwa AfD adalah partai yang berhaluan sayap kanan. Lees melihat bahwa AfD berkembang sebagai partai yang bersarang dalam profil ideologi populisme sayap kanan ortodoks Eropa (Lees 2018). Artikel ini mencoba untuk menjawab pertanyaan tentang bagaimana AfD berkembang menjadi partai politik terbesar ketiga di Jerman sejak tahun 2013 hingga tahun 2017 dan signifikansi ideologi AfD (euroscepticism dan populism) terhadap perpolitikan di Jerman. Lees menggunakan historical institutionalism dan regional integration serta menggunakan metode kualitatif deskriptif dalam menganalisis topik ini. Hasil dari riset Lees menyatakan bahwa perkembangan partai AfD di 
Jerman yang bisa dibilang pesat merupakan output dari gabungan faktor internal - efektivitas pemimpin dan penyampaian pesan kampanye, serta faktor eksternal - krisis Euro dan krisis imigran tahun 2015 yang juga melahirkan radikalisasi.

Ketiga, Podobnik, et al., (2017) dalam Predicting the Rise of EU Right-Wing Populism in Response to Unbalanced Immigration, menganalisis munculnya tren populisme sayap kanan di Eropa secara keseluruhan. Esai ini menggunakan supranasionalisme Eropa, globalisme, dan populisme sebagai landasan teori untuk menjawab pertanyaan tentang bagaimana arus imigrasi mempengaruhi munculnya tren populisme sayap kanan di Eropa. Esai ini menggunakan metode kuantitatif dan menggunakan data primer yang didapat dari jumlah vote dan interest masyarakat sebagai metode dan bahan analisis. Podobnik, et al., dalam esai ini bersepakat bahwa penyebab naiknya tren populisme sayap kanan disebabkan oleh ketidakseimbangan jumlah imigran yang masuk ke Kawasan Eropa sejak tahun 2010. Oleh karena itu, apabila elit pemerintah ingin meredam orang-orang sayap kanan yang cenderung nasionalis, maka harus ada keseimbangan antara jumlah imigran yang masuk dan proses integrasi antara para imigran dan penduduk asli.

Dan yang keempat, Schmitt Beck, (2017) dalam The 'Alternative für Deutschland in the Electorate': Between Single-Issue and Right-Wing Populist Party, menjelaskan tentang bagaimana AfD mendapatkan suara pada pemilihan elektorat Jerman pada tahun 2013 dengan menggunakan metode penelitian kualitatif deskriptif. Schmitt menggunakan teori populisme sebagai landasan teori dalam esai ini. Hasil dari riset ini juga menunjukkan bahwa, meskipun awal terbentuknya AfD didasarkan atas kritik mengenai Euro, faktor yang paling determinan atas mengapa AfD mendapatkan hati masyarakat Jerman adalah isu imigrasi dan identitas masyarakat Jerman.

Tinjauan pustaka yang dicantumkan di atas kemudian digunakan penulis untuk membuat kerangka berpikir dan rumusan masalah yang akan digunakan yaitu tentang bagaimana karakter populis ekstrem sayap kanan terepresentasi melalui poster kampanye partai AfD pada pemilihan legislatif tahun 2017. Tahun 2017 dipilih karena menunjukkan puncak suara AfD pada pemilihan suara parlemen di Jerman. Penelitian-penelitian yang dilakukan sebelumnya sebagian besar melakukan studi komparasi populisme sayap kanan di Amerika Serikat dan Eropa, serta membedah haluan 
atau gerakan sayap kanan - ekstrem sayap kanan. Maka dari itu, tulisan ini mencoba mengisi celah tersebut dengan memberikan deskripsi mengenai bagaimana karakter populisme ekstrem sayap kanan terepresentasi dalam poster mereka.

\section{Metode Penelitian}

Tipe penelitian yang digunakan penulis dalam menyusun penelitian ini adalah tipe analisis deskriptif yang bertujuan untuk mendeskripsikan sebuah fenomena dan karakteristiknya. Untuk menjawab rumusan masalah "Bagaimana Karakter PopulisEkstrem Sayap Kanan direpresentasikan dalam Poster-Poster Kampanye Legislatif Partai Alternative Fur Deutschland sebagai Strategi Komunikasi Politik?” teknik analisis deskriptif akan digunakan.

Batas jangkauan waktu penelitian adalah selama tahun 2017 ketika pemilihan suara di Jerman berlangsung. Selain itu, jangkauan penelitian ini juga hanya terbatas pada kampanyekampanye kedua partai yang dilakukan dengan metode visual melalui gambar-gambar poster. Sehingga penelitian selanjutnya diharapkan mampu mengisi kekosongan analisis penulis tentang media strategi komunikasi politik lainnya yang digunakan pada masa kampanye. Penelitian ini akan menggunakan metode pengambilan data sekunder yang didapatkan dari penelitian Reitz, A (2019). Adapun poster-poster yang akan dianalisis dalam tulisan ini adalah sebagai berikut.

Tabel 2.

Daftar poster yang dianalisis

\begin{tabular}{|c|l|}
\hline No. & \multicolumn{1}{|c|}{ Judul Poster } \\
\hline 1. & "Burkas? Wir Steh'n Auf Bikinis” \\
\hline 2. & "Bunte Viefalt? Haben Wir Schon" \\
\hline 3. & "Burka? Ich steh Mehr Auf Burgunder” \\
\hline 4. & "Der Islam? Passt Nich zu Unserer Küche!” \\
\hline 5. & “Volkes Stimme? Direktdemokratisch Wie in Der Schweiz.” \\
\hline 6. & "Euro-Rettung? Nicht um jeden Preis!” \\
\hline 7. & "Traditionell? Uns Gefält's.” \\
\hline 8. & "MUT ZU DEUTSCHLAND” \\
\hline 9. & "Neue Deutsche? Machen wir Selber.” \\
\hline
\end{tabular}


Alternative Für Deutschland Strategy in 2017 Germany Legislative

Election: Analysis of Posters as Visual Campaign Media

\begin{tabular}{|c|l|}
\hline 10. & "Und Was ist Ihr Grund Für Deutschland zu kämpfen?” \\
\hline 11. & "Sozialstaat? Braucht Grenzen!” \\
\hline 12. & $\begin{array}{l}\text { "Doppelspitze? Doppelt Spitze! Alexander Gauland \& Alice } \\
\text { Weidel trauen sich!" }\end{array}$ \\
\hline 13. & "The Germans? Will not finance you a better life” \\
\hline
\end{tabular}

Sumber: Reitz, A. (2019)

\section{Landasan Konsep dan Teori}

\section{Konsep Partai Populisme Sayap Kanan}

Populisme adalah haluan politik yang menunjukkan kecenderungan arah politik terhadap tren yang terjadi dalam konteks nasional, kawasan, bahkan global. Berbuir, et al., (2014) dalam The AfD and its Sympathisers: Finally a Right-Wing Populist Movement in Germany menjelaskan bahwa partai yang berhaluan populisme sayap kanan percaya setiap individu pada dasarnya adalah individu yang berdaulat. Tetapi, kedaulatan individu dalam konteks negara, selalu terbatas pada relasi kuasa yang ada pada badan pemerintahan. Maka dari itu, satu konsep dasar yang ada populisme adalah ketidakberpihakan mereka pada elit pemerintah (Berbuir \& Siri 2014). Sedangkan sayap kanan adalah konsep yang menjelaskan perilaku manusia yang selalu diidentifikasikan dengan "kami versus mereka". Sayap kanan seringkali diidentifikasi dengan sikap nasionalis seperti sifat primordialisme yang ingin selalu menjunjung tinggi norma, moral, adat, dan kebiasaan identitas kelompok (Berbuir \& Siri 2014). Pada ranah yang ekstrem, orang-orang sayap kanan, yang menjunjung tinggi nasionalisme daripada globalisme, cenderung menolak adanya arus imigrasi. Mereka melihat bahwa peristiwa imigrasi hanya akan merusak identitas kelompok yang telah terbentuk sedemikian rupa, misalnya, dalam hal budaya, norma dan aturan sosial yang ada dalam masyarakat (Berbuir \& Siri 2014).

Perilaku partai populisme sayap kanan yang muncul dan menuai popularitas dalam satu dekade terakhir ini menunjukkan tidak hanya sifat-sifat yang populis dan berhaluan sayap kanan, tetapi juga menunjukkan perilaku yang bersifat ekstrem. Jika partai populis memiliki karakteristik yang chameleon-like, yakni mengubah-ubah agenda partai sesuai dengan tren politik, dan partai populis sayap kanan adalah karakter partai tidak hanya 
bersifat chameleon-like, tetapi juga bersifat nasionalis dan primordial, maka partai populis ekstrem sayap kanan adalah gabungan sifat chameleon-like dan sifat nasionalis dengan level yang ekstrem. Mudde menjelaskan bahwa perilaku yang seringkali muncul pada partai populis ekstrem sayap kanan adalah nasionalisme, xenofobia, rasisme, sentimen anti-demokrasi dan keinginan untuk membentuk sebuah negara yang kuat (Carter 2005).

Carter menambahkan bahwa dua elemen yang ada pada partai ekstrem sayap kanan adalah 1) penolakan terhadap nilai-nilai fundamental prosedur, institusi, dan konstitusi dari demokrasi, dan 2) penolakan terhadap prinsip-prinsip fundamental mengenai kesetaraan dan demokrasi.

Bagan 1.

Karakter Partai populis-Ekstrem Sayap Kanan

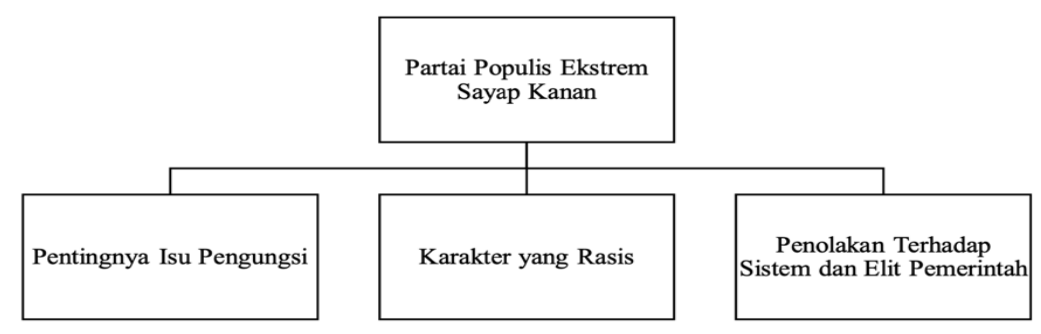

Sumber: Carter, E. (2005)

Melihat bahwa penggunaan terminologi dari populisekstrem sayap kanan masih merupakan sesuatu yang masih mengalami perkembangan karena dinamika sosial, maka untuk mengakomodasi perkembangan haluan politik ini, definisi yang akan dipakai dalam penelitian ini adalah definisi Carter mengenai populis ekstrem sayap kanan yang terdiri dari tiga karakter penting partai ekstrem sayap kanan yakni 1) agenda politik utama mereka adalah mengenai pengungsi, 2) Mempunyai karakter yang rasis, dan 3) Penolakan terhadap sistem yang ada dan elit politik (Carter, E. 2005)

1. Agenda politik utama anti pengungsi

Perilaku mereka terhadap pengungsi dapat dilihat dalam perilaku-perilaku Xenofobia dan rasisme yang diisi oleh ketakutan-ketakutan dan kebencian terhadap "the other". Oleh karena itu, dua agenda politik mereka mengenai 
pengungsi adalah homogenisasi atau mengeluarkan para pengungsi dari wilayah mereka dan mengembalikan mereka ke negara asalnya.

2. Karakter partai yang rasis

Karakter partai yang rasis dapat dilihat dalam bagaimana mereka menggunakan isu-isu perbedaan identitas dan budaya. Rasisme adalah perilaku yang meliputi prasangka buruk, kebencian, dan diskriminasi yang ditujukan kepada orang-orang yang memiliki perbedaan warna kulit, etnik, ras, agama, atau negara asal mereka. Perilaku rasisme menciptakan sebuah lingkungan yang tidak aman bagi "the other" sehingga mereka tidak bisa menikmati hak dasar mereka

3. Penolakan terhadap sistem dan elit politik

Partai ekstrem sayap kanan menunjukkan karakter penolakan terhadap nilai-nilai fundamental prosedur, institusi, dan konstitusi dari demokrasi. Karena menurut mereka, nilai-nilai demokrasi yang menjunjung kebebasan individu menyebabkan pluralisme yang dijadikan alasan untuk menampung para pengungsi.

\section{Strategi Komunikasi Politik}

Kampanye dalam pemilihan suara adalah faktor yang penting dalam politik. Strömbäck \& Kiousis menjelaskan bahwa kampanye politik adalah tentang komunikasi. Ini karena komunikasi diperlukan dalam setiap aspek kampanye termasuk dalam hal pengorganisasian, membangun aliansi dengan kelompokkelompok yang mempunyai ketertarikan dan tujuan yang sama, menggerakkan pendukung, mendapatkan perhatian media, dan membentuk nuansa informasi sedemikian mungkin sehingga kampanye yang dilakukan dilihat sebagai hal yang positif (Strömbäck \& Kiousis 2014). Strategi komunikasi politik adalah pengelolaan informasi dan komunikasi suatu organisasi yang bertujuan untuk mencapai tujuan politik yang telah ditentukan. Oleh karena itu, setiap organisasi menggunakan informasi dan komunikasi secara strategis untuk mencapai tujuan itu. Hal ini juga ditegaskan oleh Romarheim yang berpendapat bahwa hubungan politik dan komunikasi berjalan seperti darah, nadi dan arteri. Tanpa komunikasi, proses politik akan stagnan. Untuk mengerti politik secara keseluruhan, maka individu harus mengerti cara komunikasi politik dalam berbagai bentuk (Romarheim 2005). 
Strömbäck membagi kampanye politik menjadi tiga bagian sesuai dengan tipe partai saat kampanye: vote-seeking party, officeseeking party, dan policy-seeking party. Perbedaan diantara ketiganya terletak pada tujuan atau orientasi partai dan stakeholder yang dimiliki oleh setiap partai. Pertama, tujuan utama partai vote-seeking yang juga didefinisikan sebagai market-oriented party adalah untuk memaksimalkan dukungan suara kepada partai sehingga partai tipe ini menggunakan strategi intelijen pasar untuk mendeteksi apa yang para pemilih mau dan inginkan. Kedua, office-seeking party atau sales-oriented party. Tipe kedua ini memiliki tujuan utama untuk memaksimalkan kohesi internal sehingga mereka mampu memiliki kontrol terhadap politik. Ketiga, policy-seeking party atau product-oriented parties. Partai tipe ini memiliki tujuan utama untuk memaksimalkan pengaruh di dalam parlemen dan stakeholder utamanya adalah anggota parlemen dari berbagai partai (Strömbäck 2009).

Tabel 3 .

Arena dan tujuan komunikasi partai

\begin{tabular}{|l|l|l|l|}
\hline & Electoral Arena & Parliamentary Arena & Internal Arena \\
\hline $\begin{array}{l}\text { Tujuan utama komunikasi } \\
\text { di media }\end{array}$ & $\begin{array}{l}\text { Memaksimalkan } \\
\text { dukungan publik }\end{array}$ & $\begin{array}{l}\text { Memaksimalkan kekuatan } \\
\text { partai dalam proses } \\
\text { pembuatan kebijakan dan } \\
\text { negosiasi }\end{array}$ & $\begin{array}{l}\text { Memaksimalkan kohesi } \\
\text { internal partai }\end{array}$ \\
\hline $\begin{array}{l}\text { Target utama komunikasi } \\
\text { media }\end{array}$ & $\begin{array}{l}\text { Publik secara umum dan } \\
\text { potential voters }\end{array}$ & Politisi dari partai lainnya & Anggota dan aktivis partai \\
\hline $\begin{array}{l}\text { Media alternatif sebagai } \\
\text { media komunikasi }\end{array}$ & $\begin{array}{l}\text { Langsung, iklan, dan } \\
\text { media digital }\end{array}$ & $\begin{array}{l}\text { Negosiasi formal dan } \\
\text { informal }\end{array}$ & $\begin{array}{l}\text { Rapat partai, media } \\
\text { internal, media digital }\end{array}$ \\
\hline
\end{tabular}

Sumber: Strömbäck, J. and Van Aelst, P. (2013)

Selain itu, Strömbäck juga menjelaskan mengenai tiga arena yang biasanya digunakan oleh partai politik, yaitu: electoral arena, internal arena, dan parliamentary arena. Pertama, electoral arena. Dalam arena elektorat, seperti pemilihan umum, pemilihan parlemen, pemilihan kepala daerah dan lain sebagainya, tujuan utama komunikasi media partai adalah untuk memaksimalkan dukungan publik terhadap partai karena target utama komunikasi media mereka adalah publik secara umum. Selain menjadikan media massa sebagai sarana kampanye, partai dalam arena ini juga menggunakan media alternatif seperti laman web dan media sosial secara langsung dan aktif. Hal ini diperlukan karena partai dalam arena ini harus mampu menjangkau, berkomunikasi, dan mempengaruhi voters dan opini publik. 
Kedua, partai-partai yang bermain dalam arena parlemen. Dalam arena parlemen, tujuan mereka bukan lagi tentang bagaimana mereka mampu memaksimalkan jumlah pemilih mereka melainkan tentang memaksimalkan pengaruh legislatif. Pengaruh media bagi partai dalam tipe ini sangatlah kecil karena mereka sudah tidak lagi membutuhkan rekognisi tentang representasi. Apabila partai dalam electoral arena menggunakan media untuk menarik publik, partai dalam arena parlemen menggunakan media sebagai sarana untuk mengirim sinyal pada partai atau kelompok aliansi lain ketika mereka mengajukan suatu proposal hukum atau kebijakan tertentu. Media dibutuhkan oleh mereka untuk memframing suatu perdebatan sehingga posisi mereka dalam legislasi menjadi lebih kuat.

Ketiga, partai dalam arena internal. Partai dalam arena ini adalah tipe arena ketika partai paling tidak membutuhkan peran media karena tujuan utama partai dalam arena ini adalah untuk menjaga kohesi internal, sehingga mereka menuntut anggota partai mereka untuk mendukung dan secara eksternal membela kandidat lain yang direpresentasikan oleh partai mereka. Mereka tidak menginginkan kehadiran media karena logika media biasanya hanya tertarik pada drama dan konflik internal. Sehingga, mereka mengusahakan agar media tidak mendistraksi kohesi internal partai.

Dalam kampanye politik, hubungan antara partai, arena yang sedang ditempati partai dan peran media adalah faktor yang penting dalam strategi kampanye politik. Plasser \& Leangauer menjelaskan bahwa media massa memiliki peran penting dalam kampanye politik, karena tidak hanya sebagai sumber saluran informasi dan komunikasi, tapi ia juga berperan sebagai platform yang menyediakan arena politiknya sendiri. Itu mengapa debat politik yang disiarkan di televisi menjadi sangat penting bagi kandidat. Tidak hanya memberikan informasi tambahan tentang kandidat yang akan dipilih, debat politik juga menjadi arena politik tersendiri pada masa kampanye.

Seiring berkembangnya teknologi, platform kampanye tidak hanya melalui media massa konvensional saja, tetapi mulai merambah ke media digital. Davis (2009) dalam The Role of Blogs in American Politics menjelaskan bahwa dalam dekade terakhir, media digital melalui media sosial, situs web, dan blog menjadi platform yang tidak kalah pentingnya dengan media massa konvensional. Oleh karena itu, saat ini saluran informasi dan komunikasi partai 
politik saat kampanye saat ini tidak hanya dilakukan di media massa konvensional saja, tetapi juga media digital yang juga mempunyai peranan yang tidak kalah penting seperti media sosial, unggahan di blog partai, dan lain sebagainya. Apapun tipe partainya, baik vote-seeking party, office-seeking party, ataupun policy-seeking party, ketiga tipe partai ini membutuhkan media sebagai sarana komunikasi yang disesuaikan dengan arena yang sedang digunakan oleh partai.

Salah satu media yang masih banyak digunakan di negara-negara di kawasan Eropa adalah media visual (Kjelsen 2008). Salah satu bentuk dari kampanye visual adalah penyebaran poster. Kampanye visual dalam bentuk poster sebenarnya sudah dan selalu menjadi bagian dari kampanye politik sejak dulu dan sampai saat ini masih menjadi salah satu elemen yang penting dalam komunikasi politik pada masa kampanye di negara-negara Eropa.

Kampanye visual memegang peranan yang penting dalam proses kampanye politik karena pertama, apabila dibandingkan dengan teks yang tertulis ataupun orasi, wawancara, dan debat yang dilakukan secara oral, masyarakat lebih mudah mempercayai apa yang mereka lihat (Grabe 2009). Kedua, pesan-pesan kampanye yang disampaikan melalui visual atau gambar cenderung lebih mudah diingat karena mereka mampu menyalurkan pesan-pesan yang lebih sulit untuk disalurkan melalui teks ataupun oral. Ketiga, kampanye visual lebih mudah dipersonalisasikan dan dimodifikasi sebagaimana kandidat atau partai politik tertentu menginginkan diri atau kelompoknya diimajinasikan. Hal ini memungkinkan karena kampanye visual tidak mempunyai banyak batasan atau sensor sebagaimana wawancara, orasi, atau debat yang disampaikan melalui saluran televisi ataupun radio terutama di negara-negara di Eropa.

Poster dipilih sebagai salah satu media analisis karena penggunaannya sebagai salah satu media kampanye telah menjadi budaya yang telah berlangsung pasca revolusi Perancis dan masih banyak dipraktikkan hingga saat ini di Jerman (Holtz-Bacha \& Kaid 2014). Hal ini karena regulasi Jerman yang membatasi kampanye melalui iklan-iklan di TV, seperti kebanyakan negaranegara di Kawasan Eropa lainnya (Holtz-Bacha \& Kaid 2014). Selain pembatasan kuota airtime untuk iklan kampanye, harga pemasangan iklan di TV juga lebih mahal dibandingkan poster. Oleh karena itu, sampai saat ini, partai-partai di kedua negara tersebut mengeluarkan setidaknya 20\% anggaran untuk kampanye 
Alternative Für Deutschland Strategy in 2017 Germany Legislative Election: Analysis of Posters as Visual Campaign Media

yang khusus dilakukan melalui poster.

Bagi partai dan kandidat politik, poster adalah strategi kampanye yang mudah diakses karena 1) regulasi mengenai kampanye di televisi dan radio yang sarat akan peraturan dan sangat dibatasi, 2) harga pencetakan poster yang sangat murah apabila dibandingkan dengan harga iklan di televisi sehingga penggunaan poster lebih bisa menjamin persebaran yang lebih luas karena bisa dicetak dengan jumlah yang lebih banyak, dan 3) persebaran exposure yang lebih tinggi karena poster mengandalkan exposure atas informasi partai yang berulang karena poster dicetak dan ditempel di jalanan yang memungkinkan perasaan familier dengan partai.

\section{Analisis Poster Kampanye Partai Alternative Fur Deutschland}

\section{Pentingnya Isu Pengungsi Bagi Partai}

Pentingnya isu pengungsi bagi partai AfD terlihat pada empat poster yakni poster 1,2,3, dan 4 yang berjudul "Burkas? Wir Steh'n Auf Bikinis!” (Burka? Kami lebih suka (memakai) bikini), "Bunte Viefalt? Haben Wir Schon!" (Keragaman Budaya? Kami sudah memilikinya!), "Burka? Ich Steh Mehr Auf Burgunder." (Burka? Kami lebih suka (meminum) Wine), dan "Der Islam? Passt Nich zu Unserer Kuche.” (Islam? Tidak berhak ada di dapur kami). Pentingnya isu pengungsi dalam poster-poster ini terlihat dalam elemen ikonografi, atribut dan salience yakni ide yang disampaikan melalui teks dan apa yang menjadi sorotan dalam poster. Penomoran pada analisis ini akan didasarkan pada nomor poster di daftar poster pada tabel 2. 


\section{Gambar 1.}

Poster 1 "Burkas? Wir steh'n auf Bikinis"

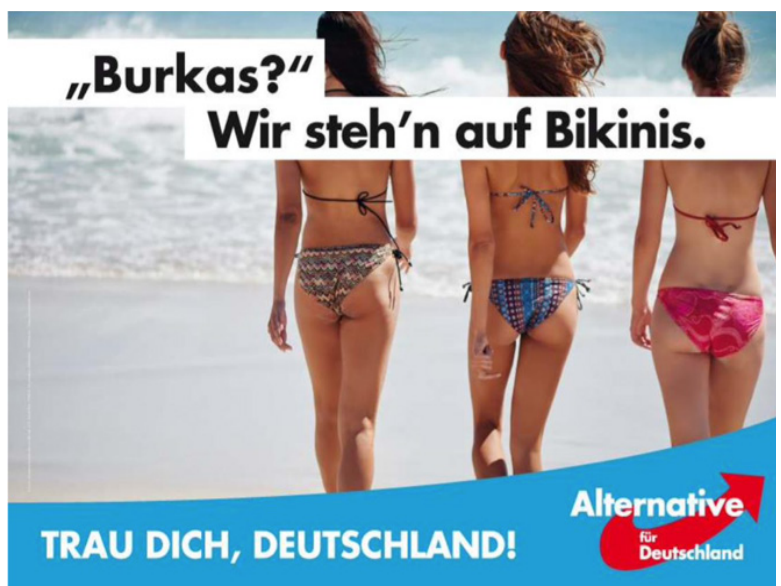

Sumber: dikumpulkan oleh penulis

Pada poster 1, penggambaran dikotomi Burka dan Bikini sebagai ikon memperlihatkan pentingnya isu pengungsi yang diwakilkan oleh Burka sebagaimana sebagian besar pengungsi yang masuk ke wilayah Jerman pada krisis pengungsi Eropa tahun 20142015 berasal dari kawasan Timur Tengah yang hampir semua masyarakatnya beragama Islam. Pesan yang disampaikan oleh AfD melalui atribut dan salience adalah masyarakat Jerman sudah terbiasa memakai bikini di pantai. Sedangkan, kebiasaan para pengungsi yang sebagian besar adalah Muslim memakai Burka. Sehingga AfD melalui poster ini menyatakan bahwa kebiasaan yang seperti itu tidak cocok dengan kebiasaan-kebiasaan orang Jerman. Mereka lebih suka memakai dan melihat orang-orang memakai Bikini daripada Burka. 


\section{Gambar 2.}

Poster 2 "Bunte Viefalt? Haben wir Schon"

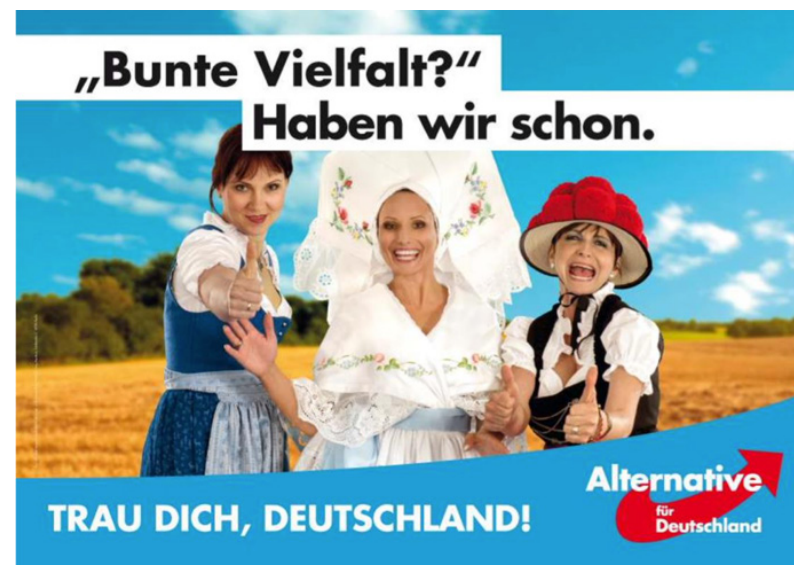

Sumber: dikumpulkan oleh penulis

Pada poster 2, pentingnya isu pengungsi terlihat dari elemen Atribut dan salience. Attribute atau ide yang ingin disampaikan melalui ikon dan kalimat yang tertulis dalam poster tersebut dengan kata "Bunte Viefalt?" dengan tanda tanya, adalah pernyataan AfD bahwa apabila yang diinginkan oleh pemerintah Jerman dengan membuka pintu kepada para pengungsi adalah keanekaragaman ${ }^{3}$, AfD menyatakan bahwa tanpa adanya para pengungsi, Jerman telah memiliki keanekaragaman. Maka dari itu, mereka tidak memerlukan kedatangan para pengungsi, untuk alasan keanekaragaman budaya. Selain itu, Setting atau nuansa yang ditampilkan adalah keceriaan masyarakat Jerman dengan keanekaragaman yang telah mereka miliki. Serta, juga seperti poster sebelumnya, hal yang menjadi salience atau highlight adalah kata dengan dua tanda koma dan tanda kutip dalam poster ini adalah “Bunte Viefalt?” yang mempertanyakan wacana keanekaragaman yang dijadikan justifikasi untuk membuka pintu bagi dan untuk menerima kehadiran para pengungsi.

3 Salah satu alasan atas perencanaan Open Door Policy Angela Merkel selain karena alasan kemanusiaan adalah alasan diversitas budaya Jerman. Wacana inilah yang dikritik oleh AfD melalui poster ini. Lihat The Economist. (2018). Germany is becoming more open and diverse. Diakses dari https://www.economist.com/leaders/2018/04/14/germany-is-becoming-more-open-and-diverse pada 18 April 2021. 


\section{Gambar 3 .}

Poster 3 "Burka? Ich steh mehr auf Burgunder"

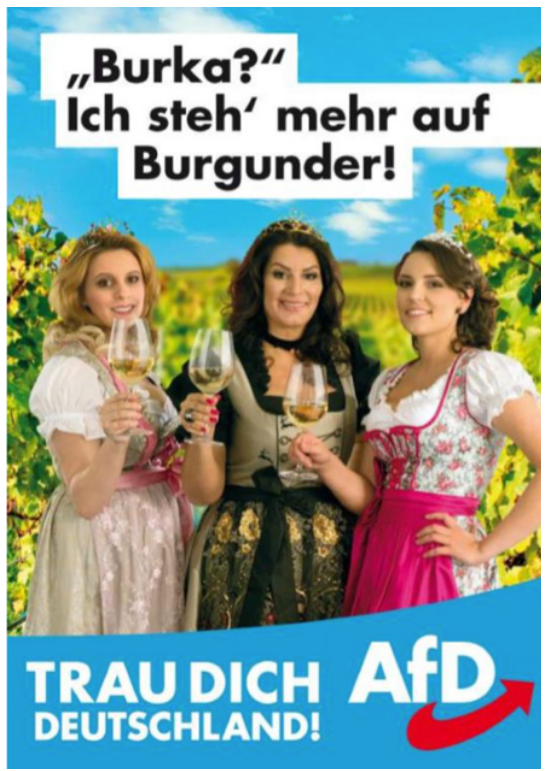

Sumber: dikumpulkan oleh penulis

Pada poster 3, pentingnya isu pengungsi bagi partai juga diperlihatkan melalui elemen atribut dan salience. Pada poster ini, partai AfD menuliskan [,,Burka?” Ich stech' mehr auf Burgunder!] atau dalam Bahasa Indonesia [„,Burka?” Saya lebih suka anggur merah!] dengan kata Burka yang ditulis dalam dua tanda koma dan tanda kutip sehingga kata 'Burka' disini menjadi highlight dari kalimat yang ada dalam poster tersebut. Atribut atau ide yang dikomunikasikan oleh AfD melalui poster ini adalah bagaimana masyarakat asli Jerman (yang diwakilkan dengan tiga perempuan memakai dirndl) lebih menyukai minuman anggur daripada Burka yang dilihat sebagai budaya yang dibawa oleh pengungsi - dan identitas pengungsi wanita Muslim. Pemilihan kata Burgunder dipilih karena kedua kata memiliki tiga huruf depan yang sama yaitu "Bur". 


\section{Gambar 4.}

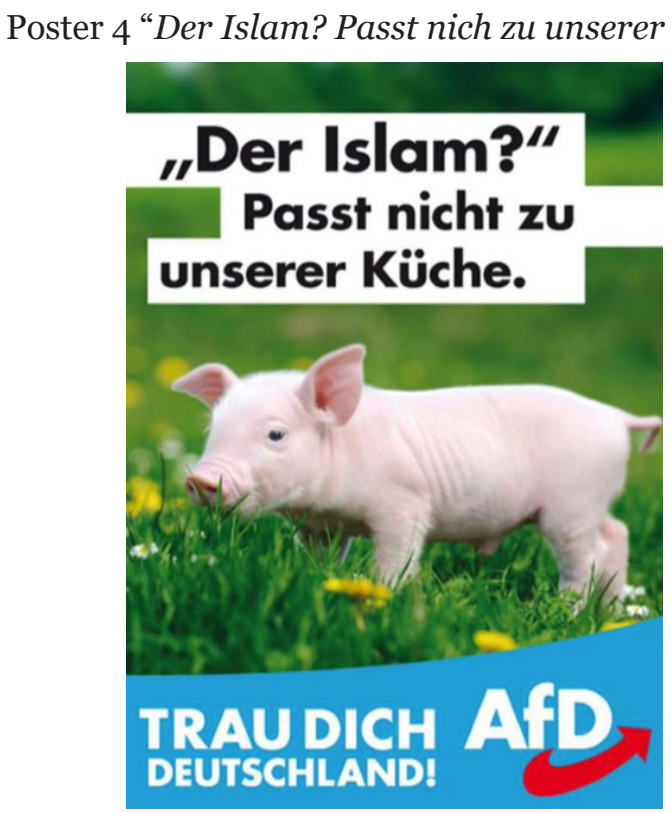

Sumber: dikumpulkan oleh penulis

Pada poster 4, salience dalam poster ini, seperti biasa, juga diwakilkan melalui kalimat yang tertulis di poster yakni „Der Islam" atau "Islam". Selain itu, atribut yang disampaikan dalam poster adalah kalimat selanjutnya dalam poster yakni "Passt nich zu unserer Küche" yang dalam bahasa Indonesia berarti "tidak seharusnya di dapur kita". Melalui poster ini, pesan yang disampaikan oleh AfD adalah Para pengungsi yang mayoritas beragama Islam tidak cocok dengan kebiasaan masyarakat Jerman karena orang-orang Jerman memakan babi.

\section{Karakter Rasis Partai}

Elemen-elemen yang menjelaskan karakter partai yang rasis hampir sama dengan elemen-elemen yang terdapat pada karakter Pentingnya Isu Pengungsi bagi partai. Ini karena pembahasanpembahasan mengenai pengungsi yang seringkali dibahas oleh AfD adalah pembahasan yang bersifat nasionalisme, termasuk pembahasan mengenai budaya (Alternative Für Deutschland, 2017). Karakter rasis partai terlihat pada poster 1, 2, 3, 4, dan 9, yang berjudul "Burkas? Wir Steh'n Auf Bikinis!" (Burka? Kami lebih suka (memakai) bikini), "Bunte Viefalt? Haben Wir Schon!" 
(Keragaman Budaya? Kami sudah memilikinya!), "Burka? Ich Steh Mehr Auf Burgunder." (Burka? Kami lebih suka (meminum) Wine), "Der Islam? Passt Nich zu Unserer Kuche." (Islam? Tidak berhak ada di dapur kami), dan "Neue Deutsche?" Machen wir selber" (Generasi Baru Jerman? Kami bisa membuatnya sendiri!). Karakter ini terlihat terutama pada elemen ikonografi, atribut, dan salience. Seperti yang terdapat pada karakter pertama, atribut dan salience ditunjukkan melalui teks pada poster yang menjadikan Burka sebagai tandingan dari budaya atau kebiasaan masyarakat Jerman.

\section{Gambar 5 .}

Poster 1 "Burkas? Wir steh'n auf Bikinis"

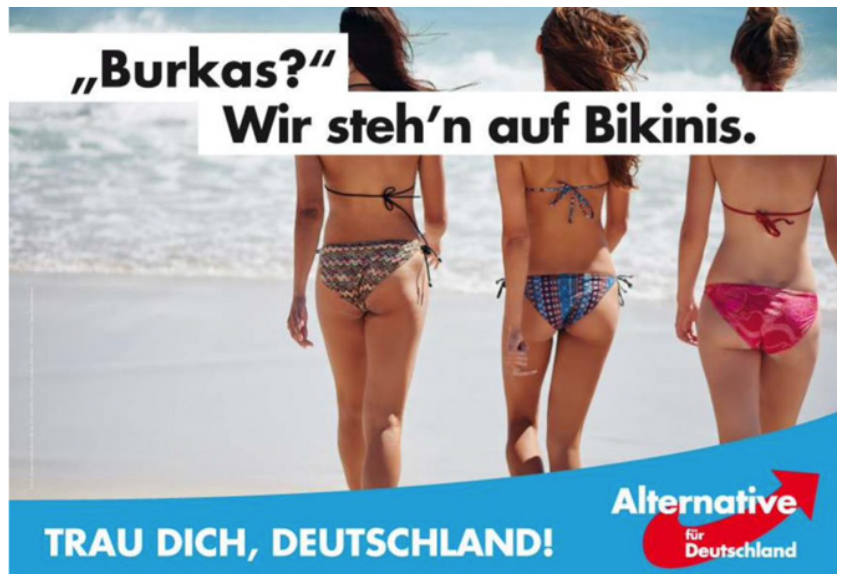

Sumber: dikumpulkan oleh penulis

Pada poster 1, seperti karakter pentingnya isu pengungsi yang telah dianalisis sebelumnya, karakter rasis partai juga terlihat pada Atribut dan salience yang menjadikan Burka vs Bikini sebagai fokus utama poster. Ini juga ditunjukkan dengan penggambaran tiga wanita sebagai yang sedang memakai bikini sebagai ikon. Seperti halnya yang telah dijelaskan di bab sebelumnya, rasisme yang dimiliki oleh partai populis-ekstrem sayap kanan adalah tipe neo-rasisme atau rasisme kultural yang menyoroti perbedaanperbedaan budaya daripada perbedaan-perbedaan fisik. Oleh karena itu, penggunaan dikotomi Burka vs Bikini yang digunakan oleh AfD dalam poster ini dapat dikatakan sebagai sikap rasis yang menjadikan kebiasaan masyarakat Jerman untuk memakai Bikini tidak seharusnya disandingkan atau diubah oleh Burka yang merupakan kebiasaan para pengungsi yang berasal dari kawasan Timur Tengah. 


\section{Gambar 6.}

Poster 2 "Bunte Viefalt? Haben wir schon"

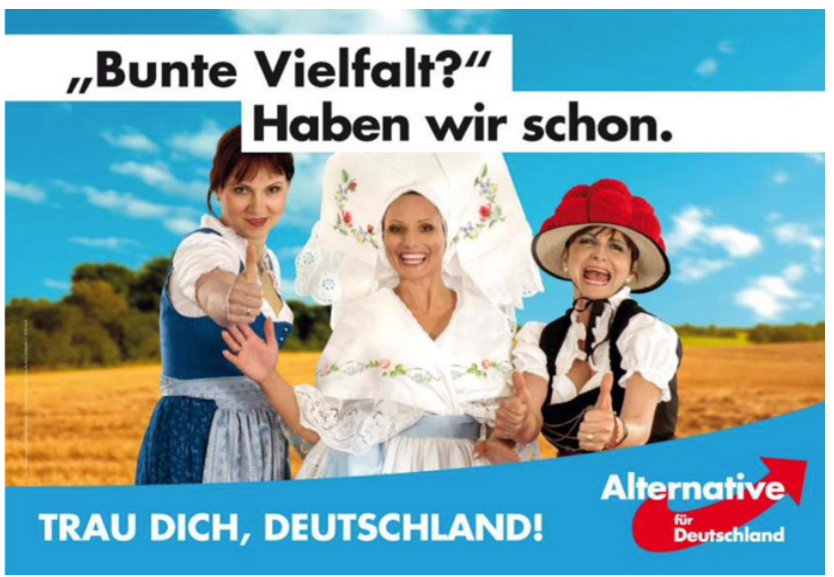

Sumber: dikumpulkan oleh penulis

Pada poster 2, karakter rasis partai terlihat lebih jelas pada ikonografi dengan menjadikan tiga wanita Jerman sebagai ikon utama. Ketiga wanita ini masing-masing menggunakan pakaian tradisional Jerman. Dari sebelah kiri, setiap wanita menggunakan Drindl $^{4}$, Lapa ${ }^{5}$, dan Bollenhut ${ }^{6}$ yang mewakili daerah yang berbeda-beda di Jerman. selain terdapat pada ikon, karakter rasis partai juga terlihat pada atribut dan salience partai yakni "Bunte Viefalt?" Haben Wir Schon" yang berarti "Keragaman budaya? Kami telah memilikinya). Ide yang ingin disampaikan melalui 4 Dirndl adalah pakaian tradisional masyarakat Jerman yang dikenakan oleh perempuan, terdiri dari korset, blus yang dipakai di bawah korset, rok berpinggang tinggi, dan apron. Drindl biasanya digunakan sebagai pakaian untuk melakukan pekerjaan-pekerjaan rumah sehingga Drindl terbuat dari bahan yang mudah dicuci dan tidak berat ketika digunakan. Lihat Herber. (2015). Germany's traditional threads. Diakses dari https://www.dw.com/ en/germanys-traditional-threads/g-17479536 pada 14 Februari 2021

5 Lapa adalah pakaian tradisional yang digunakan oleh Spreewälder innen atau wanita dari daerah Spreewalder, Bradenburg, Jerman. Pakaian ini terdiri dari rok atau cosula, Apron berbahan dasar renda, dan pita berwarna yang menandakan status perkawinan dari seorang wanita. Lihat https://www.spreewald.de/en/spreewald-holiday/culture-and-tradition/spreewald-costumes/

6 Bollenhut atau Topi Bola adalah pakaian tradisional yang dikenakan oleh wanita Protestan dari daerah Pegunungan Black Forest yang terdiri dari tiga daerah yakni Gutach, Kirnbach, dan Hornberg-ReichenBach. Bola-bola yang terletak di atas topi menandakan status perkawinan seorang wanita. Merah apabila belum menikah, dan hitam apabila telah menikah. Lihat Herber. (2015). Germany's traditional threads. Diakses dari https:// www.dw.com/en/germanys-traditional-threads/g-17479536 pada 14 Februari 2021 
ikon dan kalimat yang tertulis dalam poster tersebut dengan kata "Bunte Viefalt?" dengan tanda tanya, adalah pernyataan AfD bahwa apabila yang diinginkan oleh pemerintah Jerman dengan membuka pintu kepada para pengungsi adalah keanekaragaman7, AfD menyatakan bahwa tanpa adanya para pengungsi, Jerman telah memiliki keanekaragaman. Maka dari itu, mereka tidak memerlukan kedatangan para pengungsi, hanya untuk alasan keanekaragaman budaya.

\section{Gambar 7.}

Poster 3 "Burka? Ich steh mehr auf Burgunder"

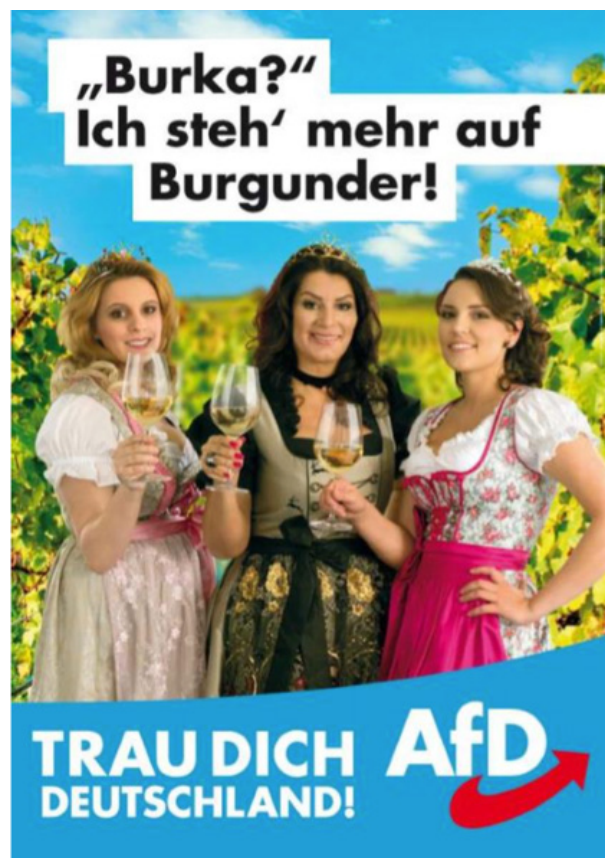

Sumber: dikumpulkan oleh penulis

Pada poster 3, karakter rasis juga ditunjukkan melalui ikonografi yang menampilkan tiga wanita yang sedang menggunakan Drindl

dan didukung dengan atribut dan salience poster yang menjadikan Burka vs Wine sebagai dikotomi. Jerman termasuk salah satu 10

7 Salah satu alasan atas perencanaan Open Door Policy Angela Merkel selain karena alasan kemanusiaan adalah alasan diversitas budaya Jerman. Wacana inilah yang dikritik oleh AfD melalui poster ini. Lihat The Economist. (2018). Germany is becoming more open and diverse. Diakses dari https://www.economist.com/leaders/2018/04/14/germany-is-becoming-more-open-and-diverse pada 18 April 2021. 
negara dengan produksi wine terbanyak di dunia (Statista 2019). Selain itu, Jerman juga termasuk 10 negara teratas di dunia yang memproduksi bir (Statista 2019). Oleh karena itu, minuman beralkohol seperti yang telah disebutkan sebelumnya menjadi drinking culture di Jerman. Sehingga melalui poster ini, melalui atribut dan salience yakni "Burka? Ich stech'mehr auf Burgunder" (Burka? Saya lebih suka wine!) AfD menyampaikan pesan bahwa budaya masyarakat Jerman adalah minuman-minuman tersebut dan bukanlah Burka.

\section{Gambar 8.}

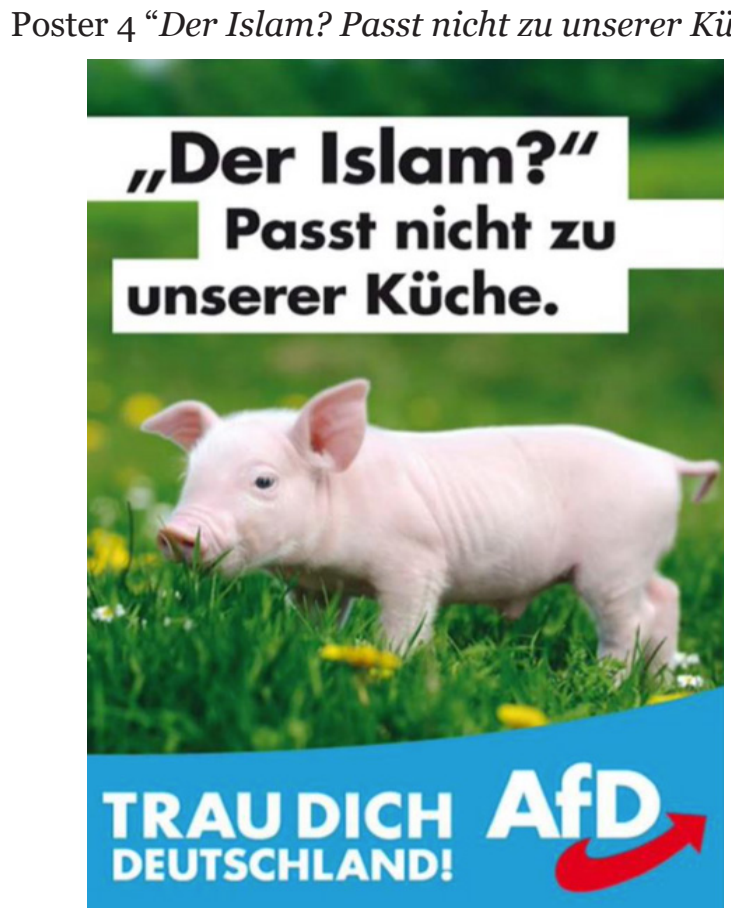

Sumber: dikumpulkan oleh penulis

Pada poster 4, karakter rasis ditunjukkan oleh Ikonografi, atribut dan salience yang bertuliskan "Der Islam?” Passt nicht zu unserer Küche.” Yang berarti (Islam? Tidak berhak ada di dapur kami). Meskipun ikon dalam poster ini tidak menggunakan ikon-ikon dengan atribut kebudayaan seperti pada poster 2 dan 3, gabungan antara ikon, atribut, dan salience Poster ini menunjukkan karakter rasisme kultural yang ditunjukkan melalui atribut dan salience yang mengangkat tema bahwa Islam tidak berhak menurut AfD untuk berada di negara mereka karena perbedaan budaya kuliner. 
Masyarakat Jerman yang mayoritas tidak beragama Islam memakan daging babi sedangkan para pengungsi yang berasal dari kawasan Timur Tengah dan hampir - kalau tidak semua beragama Islam tidak memakan daging babi karena daging babi haram bagi mereka.

Gambar 9.

Poster 9 "Neue Deutsche? Machen wir Selber"

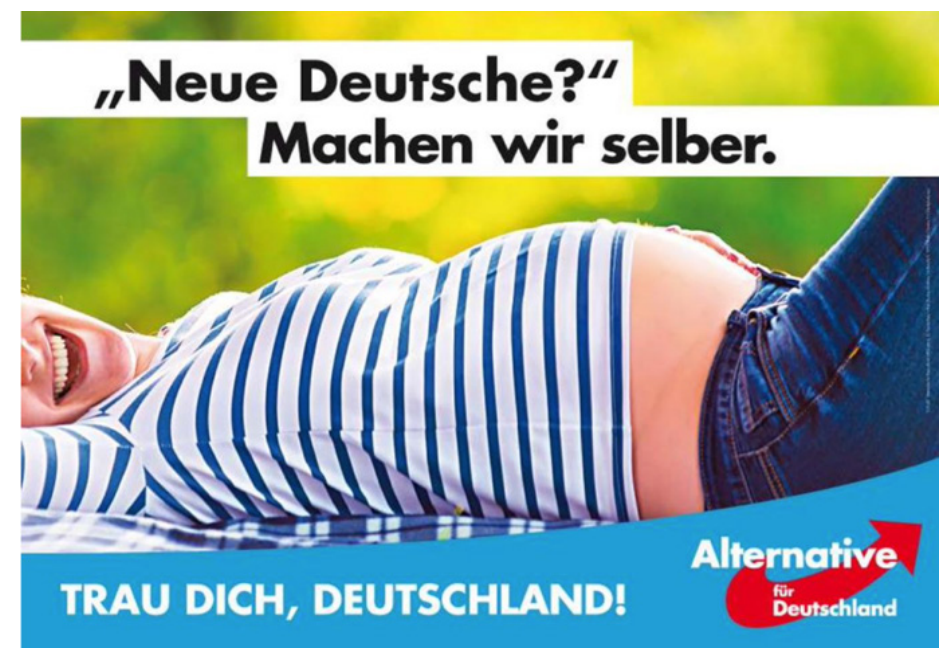

Sumber: dikumpulkan oleh penulis

Terakhir, pada poster 9 ini, gabungan ikonografi, atribut dan salience juga menunjukkan karakter rasis partai. Poster yang menampilkan perempuan berkulit putih dan berambut pirang dengan senyum lebar dan perut yang sedang mengandung ini memiliki pesan yakni "Neue Deutsche?" Machen wir selber" yang berarti "Generasi baru Jerman? Kami bisa membuatnya sendiri". Melalui atribut dan salience ini, AfD menyampaikan bahwa generasi masyarakat Jerman selanjutnya bisa diproduksi oleh orang-orang Jerman dan bukan para pengungsi. Maka dari itu, mereka juga meng-highlight "generasi baru Jerman", yang mereka artikan sebagai orang-orang asli Jerman, dan bukanlah generasi campuran yang berasal dari perkawinan antara pengungsi dan masyarakat asli Jerman (Alternative für Deutschland 2017). 
Alternative Für Deutschland Strategy in 2017 Germany Legislative Election: Analysis of Posters as Visual Campaign Media

\section{Penolakan terhadap Pemerintah atau Sikap Oposisi}

Karakter ketiga, yakni sikap oposisi partai terhadap kebijakankebijakan yang dibuat oleh pemerintah Jerman terdapat pada poster 5, 6, dan 7 denganjudul "Volkes Stimme? Direktdemoktaisch Wie in Der Schweiz" yang dalam Bahasa Indonesia berarti "Suara Rakyat? Pilih Demokrasi langsung seperti di Swiss!", "EuroRettung? Nich um Jeden Preis!” yang dalam Bahasa Indonesia berarti "menyelamatkan Euro? Tidak untuk berapapun harganya!", dan "Traditionell? Uns Gefällt's" yang dalam Bahasa Indonesia berarti "Tradisional? Saya suka itu". Pada karakter ini, karakter sikap oposisi partai terlihat dalam elemen-elemen yang lebih luas yakni ikonografi, atribut, settings dan salience.

\section{Gambar 10.}

Poster 5 "Volkes Stimme? Direktdemokratisch wir in der Scheweiz"

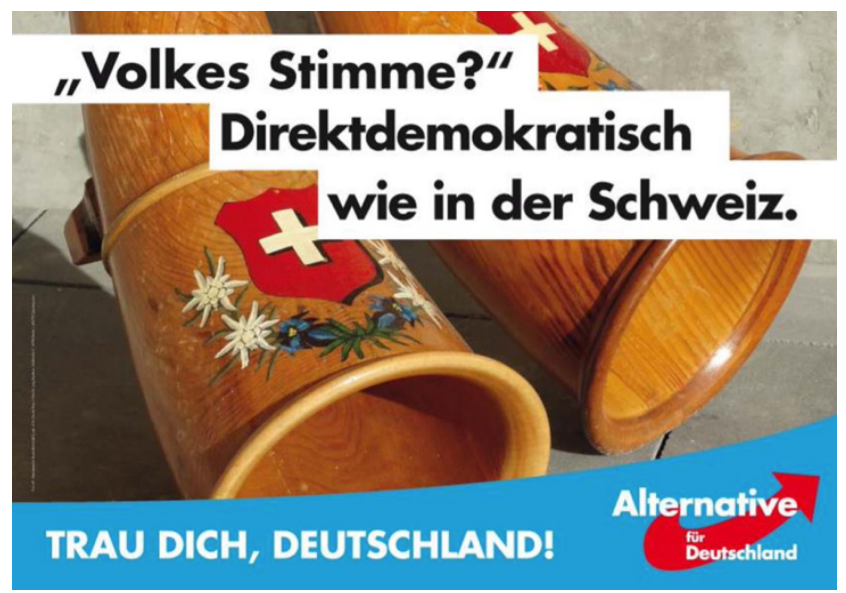

Sumber: dikumpulkan oleh penulis

Pada poster 5, Poster ini memperlihatkan sikap oposisi partai AfD terhadap sistem demokrasi yang berlaku di Jerman. Dalam poster ini, lonceng yang terbuat dari kayu dengan simbol bunga edelweis dan bunga gentian yang melambangkan tradisi orang-orang Alpen dan dijadikan sebagai simbol nasional Swiss dijadikan sebagai ikon utama. Dengan tulisan "Volkes Stimme? Direktdemoktaisch Wie in Der Schweiz" yang dalam Bahasa Indonesia berarti "Suara Rakyat? Pilih Demokrasi langsung seperti di Swiss!" yang melambangkan salience dan atribut dalam poster ini. Poster ini tidak menunjukkan karakter pentingnya isu pengungsi dan sikap rasisme, tetapi penolakan Jerman terhadap sistem demokrasi di Jerman yang bagi AfD kurang melibatkan masyarakat dalam 
proses pembuatan kebijakan ${ }^{8}$.

AfD percaya bahwa dalam suatu negara, pemerintah seharusnya melayani masyarakat dan bukan sebaliknya. AfD melihat bahwa sistem politik di Jerman malah memperlakukan rakyat sebagai aktor yang melayani pemerintah dan AfD percaya bahwa praktik ini tidak seharusnya dilakukan di negara-negara yang mengklaim dirinya sebagai negara demokratis (Alternatife für Deutschland 2017). AfD menjadikan sistem demokrasi yang diimplementasikan di Swiss sebagai referensi dalam bagaimana seharusnya demokrasi dilaksanakan.

Praktik-praktik demokrasi langsungyang ingin diimplementasikan AfD di Jerman berdasarkan demokrasi langsung di Swiss diantaranya hak masyarakat untuk menentukan dan memilih regulasi, hukum, dan kebijakan yang dibuat oleh anggota parlemen, hak masyarakat untuk menginisiasi perubahanperubahan terhadap konstitusi, dan pemisahan kekuasaan antara lembaga eksekutif, legislatif, dan lembaga yudikatif. Kritik utama AfD terhadap sistem politik di Jerman adalah kurangnya partisipasi masyarakat dalam proses politik seperti pembuatan kebijakan dan penyusunan hukum. Oleh karena itu, AfD menuntut perbaikan sistem politik di Jerman untuk lebih memberi ruang bagi masyarakat untuk turut berpartisipasi dalam proses politik sehingga proses politik tidak hanya didominasi oleh elit politik saja.

8 Misalnya pada kebijakan mengenai pengungsi, AfD melihat bahwa kebijakan Open Door Angela Merkel hanyalah kebijakan yang dibuat oleh elit politik atas ego mereka namun kemanusiaan dijadikan sebagai alasan. Padahal, AfD menilai bahwa ada banyak masyarakat Jerman yang tidak sepakat dengan kebijakan tersebut, sehingga, AfD menganggap bahwa masyarakat dalam hal ini kurang dilibatkan sehingga ia menuntut sistem demokrasi Jerman menjadi sistem demokrasi langsung seperti di Swiss. Lihat https://www.migrationpolicy.org/article/new-reality-germany-adapts-its-role-major-migrant-magnet. 
Gambar 11.

Poster 6 "Euro-Rettung? Nich um jeden Preis!"

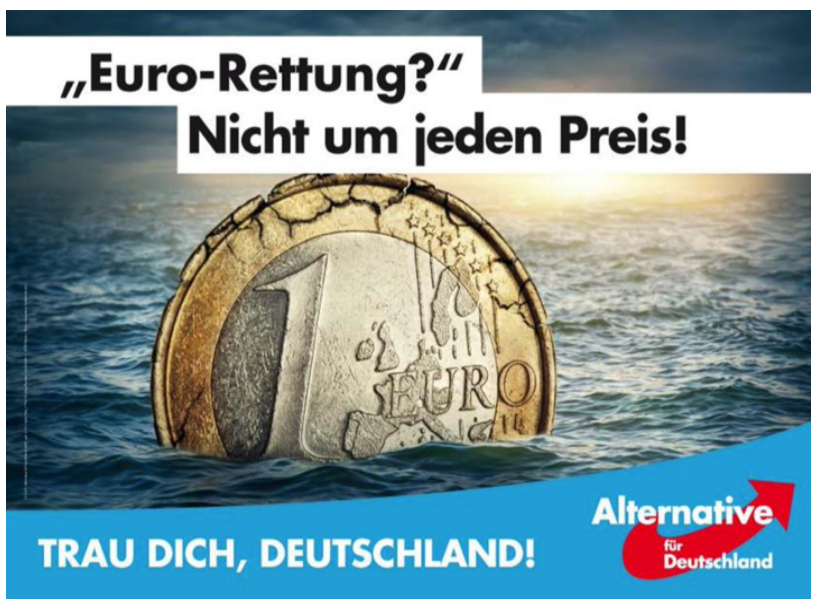

Sumber: dikumpulkan oleh penulis

Pada poster 6, gambar koin Euro yang retak dijadikan sebagai ikon utama oleh AfD. Dalam poster ini, tidak seperti poster-poster sebelumnya, poster ini tidak berbicara mengenai perbedaan budaya atau pentingnya isu pengungsi, melainkan tentang sikap oposisinya mengenai Euro. Dalam poster ini, Ikon koin Euro digambarkan dengan keadaan yang retak dan dalam keadaan mengambang di lautan dengan awan kelabu dan sedikit cahaya sebagai settings. Dengan ikon tersebut, AfD menggambarkan Euro yang hampir tenggelam. Salience dan Atribut ditunjukkan dengan kalimat "Euro-Rettung? Nich um Jeden Preis!" yang dalam Bahasa Indonesia berarti "menyelamatkan Euro? Tidak untuk berapapun harganya!”. Oleh karena itu, dalam poster ini, dapat dilihat karakter penolakan sistem atau sikap oposisi AfD terhadap pemerintah Jerman dan pemerintah EU dalam hal Euro secara khusus.

AfD percaya bahwa Euro adalah mata uang yang hanya ditujukan untuk kepentingan politik saja dan bukan untuk kepentingan ekonomi masyarakat Jerman (Alternative Für Deustchland 2017). AfD juga berpendapat bahwa Euro hanyalah mata uang uji coba yang akhirnya hanya memberikan dampak buruk bagi perekonomian negara-negara di Eropa sehingga Euro tidak seharusnya diaplikasikan di perserikatan bangsa-bangsa Eropa yang bersifat heterogen (Berbuir, N., Lewandowsky, M. \& Siri, j. 2014). AfD menolak untuk menyelamatkan Euro yang saat itu 
sedang krisis karena bagi AfD, praktik penyelamatan Euro secara konsisten menyalahgunakan peraturan pendanaan keuangan negara yang diatur oleh Bank Sentral Eropa (ECB) (Alternative Für Deustchland 2017). Hal tersebutlah yang akhirnya membahayakan perdamaian bangsa-bangsa Eropa. Oleh karena itu, AfD menolak untuk menyelamatkan Euro dan menuntut Jerman untuk menghentikan partisipasinya dalam kebijakan penyelamatan Euro yang menurut AfD pengaplikasiannya cacat secara hukum dan ekonomi.

\section{Gambar 12.}

Poster 7 “Traditionell? Uns gefällt's"

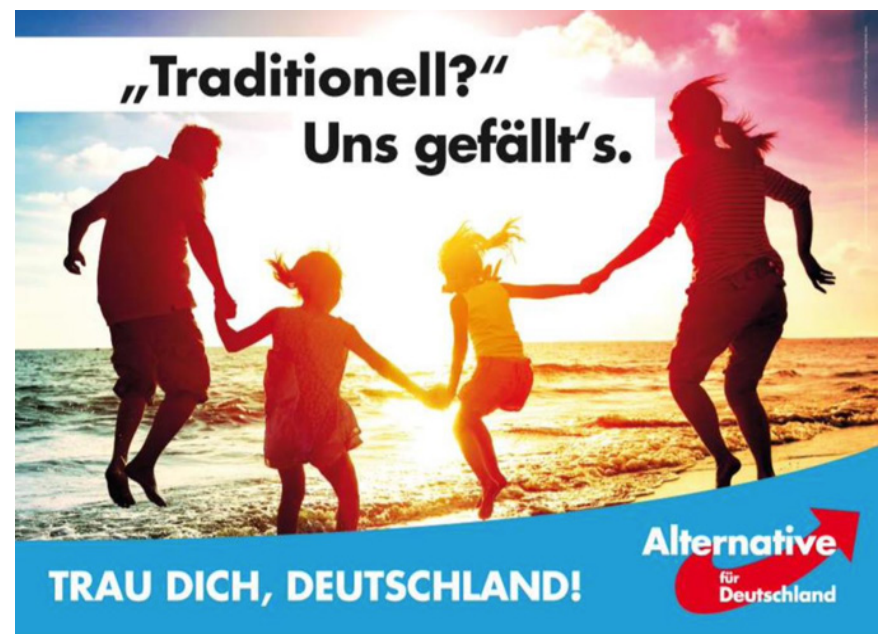

Sumber: dikumpulkan oleh penulis

Pada poster 7 ini, AfD menjadikan sebuah keluarga yang terdiri dari ayah, ibu, dan dua anak yang sedang bermain di pantai sebagai ikon. Suasana keluarga yang riang yang digambarkan dengan mereka berlompat dan bermain dengan ombak dijadikan sebagai settings dalam poster ini. Sedangkan salience dan atribut poster ditunjukkan dengan tulisan "Traditionell? Uns Gefällt's" yang dalam Bahasa Indonesia berarti "Tradisional? Saya suka itu". Dengan kombinasi keempat elemen tersebut, dalam poster ini AfD memperlihatkan karakter sikap oposisi terhadap status quo kondisi sosial masyarakat Jerman terutama dalam hal relasi keluarga.

Bagi AfD, pernikahan dan keluarga adalah hal yang penting dalam interaksi sosial masyarakat Jerman dan seharusnya 
menjadi landasan dalam interaksi sosial sehingga pernikahan dan keluarga berhak mendapat perlindungan khusus dari pemerintah (Alternative Für Deutschland, 2017). Namun menurut AfD relasi keluarga yang berkembang di Jerman saat ini menunjukkan tanda-tanda yang tidak sehat. Ini ditunjukkan dengan apresiasi masyarakat terhadap pernikahan yang menurun dan naiknya fasilitas penitipan anak dan sistem sekolah full-day sebagai alternatif untuk membesarkan dan mendidik anak. Selain itu, feminisme yang berkembang di Jerman membuat persepsi bahwa perempuan yang bekerja lebih tinggi derajatnya daripada ibu rumah tangga (Hajek, K. 2020). AfD menyayangkan ketiadaan pemerintah Jerman dalam mengatur dan menjaga tradisi mengenai keluarga ini.

Oleh karena itu, AfD hendak mengatur ulang landasan dan persepsi masyarakat Jerman terhadap pernikahan dan keluarga. AfD ingin menetapkan bahwa nilai-nilai tradisional keluarga harus dijaga. AfD hendak memastikan bahwa anak berhak mendapatkan waktu yang maksimal dalam interaksi keluarga dan bukan di tempat penitipan anak ataupun sekolah. Kurangnya inisiatif pemerintah Jerman saat ini terhadap perlindungan pernikahan dan keluarga inilah yang hendak dikritik oleh AfD dalam poster ini.

Berdasarkan analisis poster-poster kampanye di atas, dapat disimpulkan bahwa sebagian besar dari poster kampanye AfD untuk pemilihan legislatif tahun 2017 menunjukkan karakter rasis yang dapat ditemukan dalam lima poster. Karakter rasis partai AfD ditunjukkan melalui gambar yang menjadi ikon poster dan judul yang menjadi atribut atau pesan yang disampaikan dalam poster. Karakter rasis partai dalam poster direpresentasikan melalui diantaranya Burka sebagai pakaian yang digunakan oleh wanita beragama Islam, Bikini yang dianggap sebagai kebudayaan Jerman, dan babi sebagai ikon untuk menjelaskan pesan bahwa pengungsi-pengungsi yang sebagian besar dan hampir semua beragama Islam tidak pantas berada di wilayah Jerman karena perbedaan budaya dalam hal kuliner.

\section{Simpulan}

Dengan menggunakan teori strategic political communication, partai Alternative fur Deutschland menggunakan poster sebagai salah satu media komunikasi untuk menarik lebih banyak 
dukungan dari masyarakat. Poster digunakan sebagai salah satu opsi untuk mengkomunikasikan ideologi partai karena di Jerman 1) adanya pembatasan kuota mengenai jumlah airtime yang diberikan oleh pemerintah sangat membatasi jumlah partai boleh tampil di televisi nasional, 2) harga poster yang jauh lebih murah dibandingkan dengan membeli kuota tambahan untuk penempatan di televisi, dan yang terpenting adalah 3) budaya politik Jerman yang sampai saat ini masih sangat menjunjung penggunaan poster untuk kampanye.

Selain itu, dalam menganalisis poster-poster yang digunakan kedua partai dengan menggunakan konsep Populisme Sayap Kanan dan Metode CDA, dapat disimpulkan bahwa poster-poster yang digunakan dalam kampanye AfD lebih menonjolkan karakter rasis partai yang ditunjukkan oleh data sebagai berikut: pertama, untuk pentingnya isu pengungsi bagi partai AfD, dari 13 partai yang dijadikan data dalam tulisan ini, ditunjukkan oleh 4 poster yakni poster 1,2,3, dan 4 yang berjudul "Burkas? Wir Steh'n Auf Bikinis!" (Burka? Kami lebih suka (memakai) bikini), "Bunte Viefalt? Haben Wir Schon!” (Keragaman Budaya? Kami sudah memilikinya!), "Burka? Ich Steh Mehr Auf Burgunder." (Burka? Kami lebih suka (meminum) Wine), dan "Der Islam? Passt Nich zu Unserer Kuche." (Islam? Tidak berhak ada di dapur kami). Pentingnya isu pengungsi dalam poster-poster ini terlihat dalam elemen ikonografi, atribut dan salience yakni ide yang disampaikan melalui teks dan apa yang menjadi sorotan dalam poster.

Kedua, mengenai karakter rasis partai. karakter rasis partai AfD ditunjukkan oleh 5 dari 13 poster yang dianalisis dalam tulisan ini yakni poster 1, 2, 3, 4, dan 9, yang berjudul "Burkas? Wir Steh'n Auf Bikinis!" (Burka? Kami lebih suka (memakai) bikini), "Bunte Viefalt? Haben Wir Schon!” (Keragaman Budaya? Kami sudah memilikinya!), "Burka? Ich Steh Mehr Auf Burgunder." (Burka? Kami lebih suka (meminum) Wine), "Der Islam? Passt Nich zu Unserer Kuche." (Islam? Tidak berhak ada di dapur kami), dan "Neue Deutsche?" Machen wir selber" (Generasi Baru Jerman? Kami bisa membuatnya sendiri!). Karakter ini terlihat terutama pada elemen ikonografi, atribut, dan salience. Seperti yang terdapat pada karakter pertama, atribut dan salience ditunjukkan melalui teks pada poster yang menjadikan Burka sebagai tandingan dari budaya atau kebiasaan masyarakat Jerman.

Terakhir, yakni sikap oposisi partai. dari 13 poster AfD, hanya 3 diantaranya menunjukkan sikap oposisi AfD yakni poster 5,6 , dan 
7 dengan judul "Volkes Stimme? Direktdemoktaisch Wie in Der Schweiz" yang dalam Bahasa Indonesia berarti "Suara Rakyat? Pilih Demokrasi langsung seperti di Swiss!", "Euro-Rettung? Nich um Jeden Preis!" yang dalam Bahasa Indonesia berarti "menyelamatkan Euro? Tidak untuk berapapun harganya!", dan "Traditionell? Uns Gefällt’s" yang dalam Bahasa Indonesia berarti "Tradisional? Saya suka itu". Pada karakter ini, karakter sikap oposisi partai terlihat dalam elemen-elemen yang lebih luas yakni ikonografi (I), atribut (A), settings (Se) dan salience (Sa).

\section{Tabel 4 .}

Data Poster AfD 9

\begin{tabular}{|c|c|c|c|c|c|c|c|c|c|c|c|c|}
\hline \multirow[b]{2}{*}{ Poster } & \multicolumn{4}{|c|}{$\begin{array}{l}\text { Pentingnya Isu } \\
\text { Pengungsi }\end{array}$} & \multicolumn{4}{|c|}{$\begin{array}{c}\text { Karakter Rasis } \\
\text { Partai }\end{array}$} & \multicolumn{4}{|c|}{ Sikap oposisi } \\
\hline & $\mathbf{I}$ & $\mathbf{A}$ & Se & Sa & $\mathbf{I}$ & $\mathbf{A}$ & Se & Sa & $\mathbf{I}$ & $\mathbf{A}$ & Se & Sa \\
\hline 1 & $\mathbf{x}$ & $\mathbf{v}$ & $\mathbf{x}$ & $\mathbf{v}$ & $\mathbf{x}$ & $\mathbf{v}$ & $\mathbf{x}$ & $\mathbf{v}$ & $\mathbf{x}$ & $\mathbf{x}$ & $\mathbf{x}$ & $\mathbf{x}$ \\
\hline 2 & $\mathbf{x}$ & $\mathbf{v}$ & $\mathbf{x}$ & $\mathbf{v}$ & $\mathbf{v}$ & $\mathbf{v}$ & $\mathbf{x}$ & $\mathbf{V}$ & $\mathbf{x}$ & & $\mathbf{x}$ & $\mathbf{x}$ \\
\hline 3 & $\mathbf{x}$ & $\mathbf{v}$ & $\mathbf{x}$ & $\mathbf{V}$ & $\mathbf{v}$ & $\mathbf{v}$ & $\mathbf{x}$ & $\mathbf{v}$ & $\mathbf{x}$ & $\mathbf{x}$ & $\mathbf{x}$ & $\mathbf{x}$ \\
\hline 4 & $\mathbf{x}$ & $\mathbf{v}$ & $\mathbf{x}$ & $\mathbf{v}$ & $\mathbf{v}$ & $\mathbf{v}$ & $\mathbf{x}$ & $\mathbf{v}$ & $\mathbf{x}$ & $\mathbf{X}$ & $\mathbf{x}$ & $\mathbf{x}$ \\
\hline 5 & $\mathbf{x}$ & $\mathbf{x}$ & $\mathbf{x}$ & $\mathbf{x}$ & $\mathbf{x}$ & $\mathbf{x}$ & $\mathbf{x}$ & $\mathbf{x}$ & $\mathbf{x}$ & $\mathbf{v}$ & $\mathbf{v}$ & $\mathbf{v}$ \\
\hline 6 & $\mathbf{x}$ & $\mathbf{x}$ & $\mathbf{x}$ & $\mathbf{x}$ & $\mathbf{x}$ & $\mathbf{x}$ & $\mathbf{x}$ & $\mathbf{x}$ & $\mathbf{v}$ & $\mathbf{v}$ & $\mathbf{V}$ & $\mathbf{v}$ \\
\hline 7 & $\mathbf{x}$ & $\mathbf{x}$ & $\mathbf{x}$ & $\mathbf{x}$ & $\mathbf{x}$ & $\mathbf{x}$ & $\mathbf{x}$ & $\mathbf{x}$ & $\mathbf{x}$ & $\mathbf{V}$ & $\mathbf{x}$ & $\mathbf{v}$ \\
\hline 8 & $\mathbf{x}$ & $\mathbf{x}$ & $\mathbf{x}$ & $\mathbf{x}$ & $\mathbf{x}$ & $\mathbf{x}$ & $\mathbf{x}$ & $\mathbf{x}$ & $\mathbf{x}$ & $\mathbf{x}$ & $\mathbf{x}$ & $\mathbf{x}$ \\
\hline 9 & $\mathbf{x}$ & $\mathbf{x}$ & $\mathbf{x}$ & $\mathbf{x}$ & $\mathbf{x}$ & $\mathbf{v}$ & $\mathbf{x}$ & $\mathbf{V}$ & $\mathbf{x}$ & $\mathbf{x}$ & $\mathbf{x}$ & $\mathbf{x}$ \\
\hline 10 & $\mathbf{X}$ & $\mathbf{X}$ & $\mathbf{X}$ & $\mathbf{X}$ & $\mathbf{X}$ & $\mathbf{X}$ & $\mathbf{X}$ & $\mathbf{X}$ & $\mathbf{x}$ & $\mathbf{X}$ & $\mathbf{X}$ & $\mathbf{X}$ \\
\hline 11 & $\mathbf{X}$ & $\mathbf{X}$ & $\mathbf{x}$ & $\mathbf{X}$ & $\mathbf{X}$ & $\mathbf{X}$ & $\mathbf{X}$ & $\mathbf{X}$ & $\mathbf{X}$ & $\mathbf{X}$ & $\mathbf{x}$ & $\mathbf{x}$ \\
\hline 12 & $\mathbf{x}$ & $\mathbf{x}$ & $\mathbf{x}$ & $\mathbf{x}$ & $\mathbf{x}$ & $\mathbf{x}$ & $\mathbf{X}$ & $\mathbf{x}$ & $\mathbf{X}$ & $\mathbf{X}$ & $\mathbf{x}$ & $\mathbf{x}$ \\
\hline 13 & $\mathbf{x}$ & $\mathbf{X}$ & $\mathbf{x}$ & $\mathbf{x}$ & $\mathbf{X}$ & $\mathbf{x}$ & $\mathbf{X}$ & $\mathbf{x}$ & $\mathbf{X}$ & $\mathbf{x}$ & $\mathbf{x}$ & $\mathbf{x}$ \\
\hline
\end{tabular}

Sumber: dikumpulkan oleh penulis.

Berdasarkan penjelasan di atas maka diperoleh data bahwa sebesar 30,7\% poster AfD menunjukkan pentingnya isu pengungsi bagi partai, 38\% menunjukkan karakter partai yang rasis, dan 23\% menunjukkan sikap oposisi partai. Sedangkan untuk partai $\mathrm{RN}$,

9 X menandakan absennya elemen CDA dalam karakter populis-ekstrem sayap kanan, dan $\mathrm{V}$ menandakan adanya elemen CDA dalam karakter populis sayap kanan 
sebesar $85 \%$ poster $\mathrm{RN}$ menunjukkan pentingnya isu pengungsi, $14 \%$ poster $\mathrm{RN}$ menunjukkan karakter rasis partai, dan 28\% dari poster $\mathrm{RN}$ menunjukkan sikap oposisi partai. Oleh karena itu, untuk menjawab rumusan masalah "Bagaimana Karakter Populis-Ekstrem Sayap Kanan Direpresentasikan dalam PosterPoster Kampanye Legislatif Partai Alternative Fur Deutschland dan Rassemblement National sebagai Strategi Komunikasi Politik?” maka dapat disimpulkan bahwa partai AfD lebih menunjukkan karakter Populis-ekstrem sayap kanannya melalui poster-poster yang lebih menunjukkan karakter rasis, sedangkan partai RN menunjukkan karakternya sebagai partai populis-ekstrem sayap kanan melalui bagaimana mereka menjadikan isu pengungsi sebagai isu yang penting bagi partai.

\section{Referensi}

\section{Buku}

Carter, E. 2005. The extreme right in Western Europe. Success or failure?. Manchester: Manchester University Press.

Davis, R. 2009. Typing Politics. The Role of Blogs in American Politics. New York: Oxford University Press.

Mudde, C. 2007. Populist Radical Parties in Europe. New York: Cambridge University Press

Plasser, F \& L. Günther. 2009. "Television campaigning worldwide”, In Dennis W. Johnson (ed.), Routledge Handbook of Political Management, 253-271. New York: Routledge.

Huntington, S. 1993. The clash of civilizations. New York: Simon \& Schuster. Hlm. 45-48.

Schain, M. A. 2018. Shifting Tides: Radical-right Populism and Immigration Policy in Europe and the United States. Washington, DC: Migration Policy Institute.

Strömbäck, J\&S. Kiousis. 2014. "Strategic Political Communication in Election Campaigns", In Carsten Reinemann(ed.), Political Communication. Germany: De Gruyer Mouton. 
Alternative Für Deutschland Strategy in 2017 Germany Legislative Election: Analysis of Posters as Visual Campaign Media

\section{Jurnal}

Berbuir, Nicole, M. Lewandowsky, and J. Siri. 2015."The AfD and its sympathisers: Finally a right-wing populist movement in Germany?", German Politics, 24(2): 154-178.

Cincu, A. (2017). "Far Right Populist Challenge In Europe. Alternative For Germany And The National Front", Europolity, 11(1): 21-49.

Haidt. J. 2016. "When and Why Nationalism Beats Globalism", POLICY, 32(3): 46-53.

Lees, C. 2018. 'The 'Alternative for Germany': The rise of right-wing populism at the heart of Europe", Politics, 38(3): 295-310.

Strömbäck J. 2009. "Selective professionalisation of political campaigning: A test of the party-centred theory of professionalised campaigning in the context of the 2006 Swedish election", Political Studies, 57: 95-116.

\section{Artikel Daring}

BBC News. 2016. "Migrant crisis: Migration to Europe explained in seven charts", $B B C, 4$ Maret [daring]. dalam https:// www.bbc.com/news/world-europe-34131911_[diakses 31 Oktober 2020].

Eurostat. 2017. "Immigration in EU Member States", Eurostat, 15 Desember [daring]. dalam https://ec.europa.eu/eurostat/ web/products-eurostat-news/-/EDN-20171215-1_[diakses 30 Oktober 2020].

International Organization for Migration. 2015. "How the World Views Migration”, Switzerland: International Organization for Migration, [daring]. dalam https://publications.iom. int/system/files/how_the_world_gallup.pdf [diakses 30 Oktober 2020].

Ortjens, J. 2020. "Reconstructing Europes in the Migrant Crisis: Germany, Hungary, and Russia”, University of Tartu, [daring]. dalam http://hdl.handle.net/10062/66938 [diakses 31 Oktober 2020]. 
Overseas Development Institute. 2016. "Europe's refugees and migrants: hidden flows, tightened borders, and spiralling costs", [daring]. dalam https://euagenda.eu/upload/ publications/untitled-67413-ea.pdf [diakses 5 November 2020].

Pew Research Centre. 2016. "Europeans not convinced growing diversity is a good thing, divided on what determines national identity", [daring]. dalam https://www. pewresearch.org/global/2016/o7/11/europeans-notconvinced-growing-diversity-is-a-good-thing-divided-onwhat-determines-national-identity/ [diakses 31 Oktober 2020].

Pew Research Centre. 2018. "Number of Refugees to Europe Surges to Record 1.3 Million in 2015", [daring]. dalam https:// www.pewresearch.org/global/2016/08/02/number-ofrefugees-to-europe-surges-to-record-1-3-million-in-2015/ [diakses 30 Oktober 2020].

Romarheim, A. G. 2005. "Definitions of strategic political communication".. [daring]. dalam https://www.files.ethz. ch/isn/27824/689.pdf [diakses 5 November 2020].

The Federal Returning Officer. 2017. "Bundestag Election 2017", [daring]. dalam https://www.bundeswahlleiter.de/en/ bundestagswahlen/2017/ergebnisse.html [diakses 31 Oktober 2020].

Wilhelm, A. 2018. "Think Germans Love Refugees? The results of an exclusive study on how Germans perceive refugees". [daring]. dalam https://www.tbd.community/en/a/ germans-perceptions-refugees [diakses31 Oktober 2020].

\section{Disertasi}

Reitz, A. 2019. "Political Campaign Strategies of the party Alternative for Germany: A qualitative Study of Posters for the 2017 Federal Election”, Disertasi, [daring]. dalam http://urn.kb.se/resolve?urn=urn:nbn:se:hj:diva-44369 [diakses 2 November 2020]. 
Alternative Für Deutschland Strategy in 2017 Germany Legislative Election: Analysis of Posters as Visual Campaign Media 